\title{
Bird Preening during The OLd Kingdom
}

\author{
Rasha M. Omran \\ Associate Professor, Tourism Guidance Department \\ Faculty of Tourism and Hotels, Fayoum University
}

\begin{abstract}
Animals played a very important role in Ancient Egyptian life, religion, culture and language.1 There was a very strong bond between them and the Ancient Egyptians starting from the beginning of the history of mankind.2 The Ancient Egyptians depended on them during their lifetime for producing food.3 They were also used as a way of transportation from one place to another. On the other hand, animal representations helped the Ancient Egyptians to form their writing4, their sacred beliefs and to choose their symbols.5 Because of the importance of animals and birds for the Ancient Egyptians during their daily life, they depicted them in different attitudes and manners on the walls of the tombs. They showed the birds in aggressive, group, sexual, and relief attitudes. Relief attitude of birds is considered one of the most attractive attitudes that were represented in the Ancient Egyptian art, especially on the walls of the tombs. This study aimed to spotlight on the attitudes of birds during the Old Kingdom; to shed light on all types of birds' relief attitudes during the Old Kingdom; to focus on bird preening movements as represented on the walls of the individual tombs at Saqqara during the Old Kingdom; to express the observation of Saqqara artists concerning birds' relief attitudes during the Old Kingdom; to focus on the types of scenes that included preening movements; and to explain their location in the tomb. The introductory results revealed that animals were represented in most types of the scenes, reflecting the practical (daily life) role of birds in ancient Egyptian society. The representation of birds in different attitudes and poses revealed the cleverness of the artists who dealt with animal and bird scenes more than those who dealt with human forms because the quick movements of the birds need accurate and close observation of the artists. Bird relief attitude was depicted inside a small number of tombs at Saqqara dating back to the Old Kingdom. Preening movement and wing flapping are two types of preening birds.
\end{abstract}

Keywords: Relief Attitude, Bird Preening, Preening Movements, Allopreening, Force -Feeding, Old Kingdom, Saqqara.

\section{Introduction}

Since the beginning of mankind, animals have had a great effect on different aspects in the Ancient Egyptian life. They were considered as an essential source of food production, leather and fur. They participated in ancient Egyptian' religious beliefs; as they were considered manifestations of some gods and goddesses. They were used as a way of communication in ancient Egyptian society by writing and using their whole images or parts of them. Birds also played a great effective role in art; as they were depicted on the walls of ancient Egyptian monuments like temples and tombs. Moreover, animals' representations had the ability to expose everything about the lifetime especially ancient Egyptian activities. ${ }^{6}$ Many of the Old Kingdom 
tombs' walls at Saqqara are covered with a large number of animals and birds images participating in different daily life events like marshes, fowling, poultry ${ }^{7}$ and pastoral activities including many tasks among of which are breeding and force feeding. ${ }^{8}$ Such types of activities for animals and birds were characterized by their sense of vibrant typically like in real life which is very clear through the movements of their participants. ${ }^{9}$

\section{Objectives}

1. Spotlight on the attitudes of birds during the Old Kingdom.

2. To shed light on all types of birds relief attitudes during the Old Kingdom.

3. To focus on bird preening including preening movements as represented on the walls of the individual tombs at Saqqara during the Old Kingdom.

4. To express the accurate observations of Saqqara artists concerning the relief attitude of birds during the Old Kingdom.

5. To focus on the types of scenes that included preening movements

6. To explain the specific places that are decorated with these preening scenes in Saqqara private tombs.

7. To explain preening movements of birds observed by the ancient Egyptian artist.

\section{Methodology}

The current research based on descriptive and analytical approaches that help in explaining the preening movement scenes depicted on the walls of the individual tombs at Saqqara.

\section{Bird Attitude}

Scientists define the term "attitude" as knowledge, social communication, and movement. ${ }^{10}$ Animal attitude can be determined to be a very quick reaction against others among the same species, other species or even the surroundings. It refers to survival and reproduction. It includes many activities of different species to guarantee their continuation against the circumstances in the environment like cold, hot weather, rain and parasites. In other words, animal behavior helps all kinds of animals to achieve their desired objectives. ${ }^{11}$ It must be noted that the members of the same species are typical in performing their common attitudes and completely different from the other species in executing the same attitude. ${ }^{12}$ The ancient Egyptians were fond of observing various types of animals' behaviors in terms of the sufficient information of the behaviors of different animals as well as their activities like fish ovulation and bird matting that helped them in the process of hunting. ${ }^{13}$ A large number of animal attitudes, gestures and movements represented in Ancient Egyptian art reflected the accuracy of the artists' observation for many of the animal characteristics which they pursued to explain in their art. ${ }^{14}$ Both of the pose of all the parts of the animal's body like the legs, mouth, wings and the context in which it is found like the relation between it and the others are very important methods from the ethological point of view that help in determining and analyzing the significance of attitudes and in classifying the types of them. It is worthwhile noting that the species of animals is one of the main elements which have a great effect on performing behaviors. ${ }^{15}$ There are many types of animal attitudes represented on the walls of different ancient Egyptian monuments such as locomotors, aggressive, hunting, sexual, relief. $^{16}$ 


\section{Birds in Ancient Egypt}

In Ancient Egypt, large number of birds, especially waterfowl live in the swamps of the Delta, Fayoum and around the River Nile because of migration ${ }^{17}$ due to the warm climate. Because of that, the ancient Egyptians built breeding farms. So, it can be noticed that there is a close relation between bird hunting scenes and those of breeding farms. ${ }^{18}$ They had both mundane and religious functions. The delicious types of birds as well as water fowling like geese, ducks and cranes were captured to be either sacrificed or fattened and forced - feeding until using their flesh as a source of protein or food supply for both people of high class as well as ordinary human beings. ${ }^{19}$ Although protein can be found in different types of food, animal protein in particular was preferred by the ancient Egyptians as it was considered the most important element of the human diet. ${ }^{20}$ Birds especially ducks and geese were very important during the life time because they did not only provide the ancient Egyptians with protein from meat but also from egg. ${ }^{21}$ Eggs of many birds formed a very important part in their diet and the richest source of protein. It was also used as a type of the deceased offerings during the late period and as a symbol of renewal life. ${ }^{22}$ In medicine, geese played a very important role by using their fats as an element of many prescriptions to treat many diseases like eye and digestive diseases. ${ }^{23}$ In addition, birds provided the ancient Egyptian community with feathers for making fans and arrows. ${ }^{24}$ Some birds like ducks and geese were used as a snare in order to get attention of waterfowl to catch them easily. ${ }^{25}$ Birds were also represented in writing ancient Egyptian language either as a whole or just parts of them. ${ }^{26}$ According to the ancient Egyptian religion, birds were used as sacrifice offerings for the deceased to be as a provision in their eternal life in the netherworld as they were considered a symbol of rebirth and fecundity. ${ }^{27}$ It should be noticed that, different types of fowl like duck and geese were mentioned as one of the main elements in the offering list for the deceased. ${ }^{28}$ They were called Apdwt. ${ }^{29}$ Moreover, the ancient Egyptian was eager to represent himself after death in the form a bird or human headed - bird since the New Kingdom. This form was called bA means soul. ${ }^{30}$ This form was considered as a symbol of freedom on one hand and to have the ability of flying in the sky with Re in the Netherworld on the other. ${ }^{31}$ Moreover, animals including birds played a very important role in ancient Egyptian conception. Different gods and goddesses were worshiped in different forms like complete human, complete animal or in the form of human body with the head of an animal or a bird ${ }^{32}$ like Horus, Thot, Re, Amun and Geb. ${ }^{33}$ Some other gods were represented in the form of birds like Amun who was worshiped in the form of a goose. ${ }^{34}$

\section{Daily Life Scenes in Saqqara Private Tombs}

Saqqara is considered the most famous and important archaeological site at Memphis during the Old Kingdom, especially the last two Dynasties. ${ }^{35}$ Most of the walls in rock- cut tomb chapels of the high officials at Saqqara are decorated with a large number of daily life scenes. ${ }^{36}$ According to the ancient Egyptian conception, tomb was not only a burying place for the dead body but it was also a link between life and that in the Hereafter. ${ }^{37}$ This link was achieved through many things like daily life scenes which have a religious significance of reflecting all the activities and interests of the owner of the tomb that will took place typically in the Netherworld. ${ }^{38}$ During that time, Saqqara private tombs were famous for their gifted artists as well as painted and carved scenes. ${ }^{39}$ The scenes included poultry yards and cages containing different types of domesticated birds including cranes, geese and ducks. ${ }^{40}$ This type of domesticated animals was bred in captivity for economical purposes and depending on human food supply. They are different from the others that live in the natural environment in many things, especially behaviors. ${ }^{41}$ The most famous examples of such tombs are that of the high official Ty and Ka Gemni which contain many scenes of fowling and breeding birds. ${ }^{42}$ 


\section{Relief Attitude}

Relief attitude is considered one of the categories of animal behaviors that can be acted in different ways, according to the different species. This attitude is very useful for the animals; as it enables them to be relaxed and away from any feeling of agitation or annoyance. It includes three actions like grooming, elimination and preening. ${ }^{43}$ Grooming means looking after the coat or the skin of the animal by brushing and cleaning ${ }^{44}$ as well as it contains licking, scratching and rubbing the animal's body. ${ }^{45}$ Elimination means the removal of the animal waste containing urine and feces. It should be said that animals are completely different in performing such demeanor. Finally, preening bird behavior aims to straighten, arrange and clean the feathers by using the beaks of birds. It includes two performances such as preening movements and wing flapping. ${ }^{46}$

\section{Bird Preening}

It is one of the actions of the relief attitude and a type of grooming demeanor. It is consecrated for the preservation of birds' feathers by cleaning, brushing, scratching as well as oiling the feathers. ${ }^{47}$ Oiling process is considered a type of preening which is acted by using the bills in order to spread the extracting waxy substance from the preen gland that is found close to the tail. ${ }^{48}$ Oil provides the feathers with softness and it helps the watery birds to be floated over the water without carrying water into their feathers. ${ }^{49}$ Therefore, birds of different types are used to spend a long time daily in preening especially after bathing, oiling and feeding activities. ${ }^{50}$ They do different movements during both preening and oiling processes in which they clean all the feathers covering their bodies to get rid of the parasites which live inside them. ${ }^{51}$ Head can be cleaned by scratching it, using feet either in a direct or indirect way. ${ }^{52}$ Dirt on legs and feet are removed by using the bill in nibbling. ${ }^{53}$ Birds depend on the flexibility of their bodies in cleaning their backs, necks, breasts, bellies, wings and tails. ${ }^{54}$ On the other hand, birds can clean their feathers by submerging their bodies and feathers in water. ${ }^{55}$ Bills of birds take two shapes of movement throughout preening, either nibbling to catch dirt or stroking to smooth the feathers. ${ }^{56}$ There is another type of preening called mutual or allopreening. It looks like the normal preening behavior that is acted by the bird to clean its own feathers, but in the case of allopreening, cleaning was done by one bird to another. ${ }^{57}$ The last stage of preening is called wing flapping, in which birds fuzz their feathers before flapping them. ${ }^{58}$ Wing flapping attitude can be acted either on the ground or on water with about six types of movements like stretching out the wings on both sides of the body and keeping them away of their backs and above their upper parts of their bodies. ${ }^{59}$ Finally, it should be said that cleaning the bird feathers or preening behavior is one of the most common attitudes among Aves. ${ }^{60}$

\section{Tombs with Preening Movement Scenes \\ 1. Back Preening}

The first tomb at Saqqara that includes bird back preening attitude dates to the $5^{\text {th }}$ dynasty, reign of Niuserre. ${ }^{61}$ It is situated around Unas pyramid complex without number. ${ }^{62}$ It belongs to the inspector of singers called $\mathrm{nfr} \mathrm{\theta}^{+}$and his father kA HA $\backsim$ This attitude is represented on the eastern wall of the chapel which is divided into five registers. The third register contains two scenes; baking bread to the left and fowling to the right using closing net and in the middle using crates to put in them the captured birds. Just under the crate that is held by the fowler is a headless goose (Scene 1-1) as it is represented with two wings raised up while the head disappears between them aiming to the best cleaning of the back feathers. This movement of the goose indicates what is called back preening which is achieved by twisting the head of the bird 
completely to the back. ${ }^{64}$ Worthwhile, it can be easy to differentiate between the bird in preening and the captured or rxy.t bird according to the position of the head, wings and legs of each of them. ${ }^{65}$ Another attitude of back preening is represented in the tomb of Ty $=14 .{ }^{66} \mathrm{He}$ was the overseer of the solar temples and the pyramids of the fifth dynasty. ${ }^{67}$ It carries No. 60 (D 22). ${ }^{68}$ This tomb lies to the north of the step pyramid. ${ }^{69}$ It dates back to the late of the fifth dynasty, reign of kings Djedkare Isesi and Unas. ${ }^{70}$ The scene is depicted on the southern wall of the portico to the left side. ${ }^{71}$ It contains five registers; the upper three registers represent animals and the lower two registers contain poultry- yard. The fourth register is divided into five horizontal sections; all of them represent force - feeding (Scene 2-1) and (Scene 6-1,2) different types of birds like pintail ducks and geese. ${ }^{72}$ Five birds in the four sections, starting from the left-hand side, are shown turning their heads and necks behind or twisting their heads to check the feathers of their backs with closed beaks. It is noticeable that the number is considered very few in comparison to the total number of birds. ${ }^{73}$ The movement of the head and neck of different birds especially ducks can be seen not only in wall scenes but also in some pieces of art like necklaces and spoons. ${ }^{74}$ The same attitude can be seen acted by a pintail $\operatorname{duck}^{75}$ in a scene of preparing food (Scene 2-2) for birds in the country side. It is depicted on the southern wall of the first room of the tomb of $\mathrm{mHw}$ $9 .^{76}$ This tomb lies around Unas pyramid complex, most probably reign of Pepi I. ${ }^{77}$ The same attitude is repeated by two geese in force -feeding (Scene 3-1) on the western wall of the pillared hall. The only difference in this scene is that the geese here are shown opening their beaks to nibble their plumage. ${ }^{78}$ The same behavior is shown acted by two geese in free feeding scene in which fowlers are shown throwing grain to birds (Scene 3-2). It is represented on the western wall of the chamber A $6^{79}$ and by a crane in the tomb of mrrwkA 3 ). He had many titles like vizier and the prophets' supervisor. ${ }^{80}$ His tomb dates to the reign of Teti and lies around Teti pyramid. ${ }^{81}$ Moreover, there is a representation of back allopreening performed from one goose to another which is also depicted in the same scene. The tomb of Axt Htp $\frac{A}{\Delta \square}$ which carries No. 64 (a), also includes papyrus marsh scene with a back-preening attitude of bird flying. ${ }^{82}$ It dates back to the reigns of Issesi and Unas. This tomb is situated to the west of the step pyramid Complex. ${ }^{83}$ The papyrus marsh (Scene $4-1$ ) is depicted above the doorway in the center of the eastern wall of the T- shaped chapel. ${ }^{84}$ The papyrus marsh scene contains flying birds in different performances among of which a bird is shown turning its head backward to clean the saddle plumage with its bill while raising up its wings. ${ }^{85}$ It should be noted that the pose of the bird is very rare in what is called flight preening which was difficult to be observed by the artists. Moreover, feathers conservation is usually acted while the bird is in a stable situation like standing, sitting, swimming, etc. ${ }^{86}$ Another scene of back preening belongs to the tomb of kA gmni $\cup$ who was the vizier of king Teti. His tomb carries No. LS 10. It lies around Teti pyramid. ${ }^{87}$ The scene can be seen on the western wall of room No. 4 , right section. It represents a goose in a force- feeding scene (Scene $5-1$ ) in a poultry yard ${ }^{88}$ preening its back by nibbling. It is shown opening the mouth and lifting one of its feet aiming to clean the most available parts of the body. ${ }^{89}$ This scene occupies the fourth register of sixth facing the standing figure of the owner of the tomb.

\section{Wing Preening}

Although back preening was the most popular movements of birds, especially geese during the Old Kingdom scenes such as force - feeding, some other movements can be seen side by side. One of these movements is wing preening. It is acted by bending the head beside the body to enable the beak cleaning the wing plumage. ${ }^{90}$ Tomb of $\mathrm{kA}$ gmni includes this attitude which is represented on the western wall of room No. 4, right section. It represents a goose in a force- 
feeding scene (Scene $6-1$ ) in a poultry yard. ${ }^{91}$ There is also another scene of three ducks being fed grain while one preening (Scene 6 - 2) its wings in the poultry yard. It is represented turning its head and neck and opening its beak to nibble the feathers of the neck. This Scene can be found on the western wall of room No. 4, left section. ${ }^{92}$ Another force-feeding scene (Scene $6-3$ ) represents a goose while twisting its head and neck to clean its wings with closed bill. It is represented on the same wall of (Scene $6-1) .{ }^{93}$ Another type of wing preening is preening the inner part of the wings. This attitude is very common among geese. It is depicted several times on the western wall of the portico in the tomb of Hsy that is situated around Teti pyramid. Another scene (scene 6-4) represents geese in crates instead of the poultry- farm and two feeders are standing on both sides to throw grain from sacks for the birds. It includes large number of geese; three of which are shown preening the inner part of their wings. Two of them are shown cleaning the upper part and the third one is represented cleaning the lower part. ${ }^{94}$

\section{Flank Preening}

Flank preening is performed by bending the head and the neck of the goose. ${ }^{95}$ It is represented on the right section of the western wall of room No. 4 in the tomb of kA gmni. The goose is shown a force - feeding scene (Scene 7 -1) which occupies the fourth register. ${ }^{96}$

\section{Head and Bill Preening}

Head and bill preening are very common attitudes represented in the tomb of kA gmni in a forcefeeding scene in a poultry yard (Scene 8-1) on the western wall right section of room No. $4 .{ }^{97}$ One duck and three geese are shown while scratching their heads and bills with various aspects. The first is represented turning its head while lifting one foot. The second is shown scratching the back part of its head by the foot. The third is shown scrabbling the lower part of the head by one foot, whereas the fourth goose is represented turning its head to gnaw it in the body. It should be noted that all the birds are shown with opened bills. It is preserved that the four examples are represented with twisting their heads upside down except for the third one. ${ }^{98}$ Head and bill allopreening are also represented on the walls of the tomb of mrrwkA. The scene occupies the western wall of the chamber A6 to the left-hand side. ${ }^{99}$ It represents one duck preening the head of the other by its open bill (Scene 8-2). ${ }^{100}$ Another scene (Scene 8-3) on the same wall of cranes force feeding represents bill allopreening for two cranes. It includes two cranes preening the upper and lower parts of the bills of two others, one from the lower part and the other from the upper part. ${ }^{101}$

\section{Feet Pecking}

This aspect represents how the ancient Egyptian artists were perfect enough in their observation of bird life. Tomb of kA gmni contains different scenes, including feet pecking movements. Two of these movements are performed by two geese that are represented in force-feeding scene (scene 91) in which a goose lifting one foot and nibbling it by its bill while, in (scene 9-2), the goose is shown bending the head down to the feet on the ground. These scenes occupy the fourth register of the right section of the western wall of room No. $4 .^{102}$ The third movement is represented in a preening scene (scene 9-3) of a goose that occupies the fifth register of the same wall. It is shown standing on the banks of the pool containing fishs and birds while pecking one of its feet by its bill. ${ }^{103}$ Tomb of mrri $\$ 4$ also contains two geese nibbling their feet in a force - feeding scene (scene 9-4), one of them looks like that of (scene 9-1), (scene 9-3) and the second one looks like the goose in (Scene 9-2). This scene occupies the fifth register of the west wall of the first room in 
the tomb. ${ }^{104}$ It should be noted that this tomb dates to the middle of the sixth Dynasty and lies around Teti pyramid. ${ }^{105}$ Feet pecking can be seen in force-feeding and preening scenes in general and it is very important in removing pebbles and mud from the claws. In this movement, birds are shown holding their feet up to the bill aiming to clean the claws of their toes. ${ }^{106}$ Birds sometimes bend their heads and necks totally until reaching the feet resting on the ground. ${ }^{107}$

\section{Breast Preening}

Breast feather preening is depicted several times in many tombs in different styles and with different types of birds like geese and cranes. One of these tombs is the tomb of mrrwkA. It includes breast preening scenes for both geese like (Scene 10-1) that is depicted on the west wall of chamber A6 representing a goose preening its breast by bending its neck. It is represented in a free feeding scene in a poultry yard. ${ }^{108}$ The same scene is represented in the tomb of mrri (Scene10 -2) that occupies the seventh register of the western wall of the first room. It represents some geese eating corn and fish, including one goose cleaning its breast feathers. ${ }^{109}$ Another scene of breast preening acted by a goose is represented in the tomb of Hsi. The scene here (Scene 10-3) looks like (scene 10-2) but it is represented on the western wall of the portico. ${ }^{110}$ Breast Preening is also depicted in the tomb of $\mathrm{kA}$ gmni. It represents birds standing on the banks of a pool containing fish and birds. This scene is depicted in the fifth register of the right section of the western wall in room No. 4. ${ }^{111}$ In this scene (Scene 10-4) a goose is represented to the left-hand side while preening its breast by raising its wing up. Concerning the long neck birds like cranes, they are represented in different poses throughout breast preening process. Two scenes represent cranes while preening their breasts. The crane in the first scene of free feeding is shown preening its breast by turning its neck up in (Scene 10- 5). It is represented on the northern wall of the first room in the tomb of Ni-kAw issi that lies around Teti pyramid. ${ }^{112}$ On the contrary, the second crane is represented in the other scene turning its neck upside down (Scene 10- 6). The crane here is shown in a free feeding as the servants are shown scattering grain for the fowl including cranes. This scene is depicted on the western wall of chamber A6 in the tomb of mrrwkA. ${ }^{113}$

\section{Discussion}

Before discussing the current subject, it should be mentioned that it is very difficult to match between birds represented in Ancient Egyptian scenes and those in modern times. This is due to the extinction of most of them and changing the features of others to be compatible with nature as a natural development of birds. ${ }^{114}$

Ancient Egyptian art has been passed by several stages and each stage was marked by its characteristics and objectives. During the Old Kingdom, the religion had a great effect on the artist leading him to depict all the daily life activities such as bird hunting, breeding and feeding. Saqqara private tombs are rich in large number of bird scenes that show the versatility artist in the use of bright colors, as well as his skill in portraying the diverse movements of birds with full flexibility and vitality. ${ }^{115}$

This study focused on bird preening as a type of bird relief attitude. It contains six scenes, including preening like fowling, force -feeding, papyrus marshes, preparing food, free feeding and preening. It is noticed that force - feeding occupies most scenes that include bird preening. It revealed also that there are six preening movements including back, wing, flank, head, bills, feet and breast preening. Moreover, preening scenes are shown in different locations inside the Old Kingdom private tombs at Saqqara like the chapel, portico, pillared hall T- shaped chapel and 
rooms. Preening scenes are found inside a small number of Saqqara private tombs and are scattered in four sections as follows, Around Unas pyramid Complex, North of the Step Pyramid, West of the Step Pyramid Complex and Around Teti Pyramid. The majority the scenes are shown in the tomb of $\mathrm{kA}$ gmni especially on the western wall of the room (Chamber A6) which is situated around Teti pyramid.

\section{Results}

- Birds especially geese and ducks were very important for the ancient Egyptian in both daily and religious life.

- Preening movements disappeared from the Third and Fourth Dynasties representations at Saqqara private tombs.

- Relief attitude of fowls appeared on the walls of the private tombs at Saqqara during the last two dynasties of the Old Kingdom.

- Preening movements are represented on the walls of a small number of tombs at Saqqara.

- Back preening was considered the most common performance of relief attitude as it was very noticeable among other fowl activities.

- Back Preening through flying was very rare in depiction at Saqqara during the Old Kingdom.

- Preening is a common attitude among birds especially in poultry -farms because they are very sociable species which usually imitate each other.

- Preening beneath wings is considered a common attitude among birds especially geese.

- Preening movements only represent the domesticated fowls like geese, ducks and cranes.

- Most bird preening scenes is depicted on the western walls of Saqqara private tombs which reflect their religious significance for the ancient Egyptians in addition to their daily life function.

- Allopreening or mutual preening is represented for cleaning back, head and bill.

- Geese are depicted in most scenes representing relief attitude in Saqqara necropolis.

- The representation of bird relief attitude is only represented in the daily life scenes in Saqqara private tombs dating back to the Old Kingdom.

- Bird preening is divided into six movements including back preening, Wing preening, Head and bills scratching, Feet pecking and Breast preening.

- Most bird preening movements are found in force feeding scenes.

- Tomb of kA gmni is the only tomb that contains all types of bird preening scenes.

- Tombs with bird preening scenes are found in four sectors at Saqqara necropolis like North of the Step Pyramid, West of the Step Pyramid, Around Unas Pyramid and Around Teti Pyramid.

- Preening movements' scenes were depicted in different places inside Saqqara tombs like portico, chapel and pillared hall, T-Shaped Chapel and Rooms.

- Bird preening was only represented in daily life scenes such as marshes, fowling and force feeding, free feeding and preparing food in the Old Kingdom private tombs at Saqqara.

\section{The Importance of Bird of Preening Subject in Tourism Guidance}

This subject is very important for tourist guides as it provides them with specialized information of one of the most attractive scenes depicted on the walls of the Old private tombs at Saqqara. By explaining this subject for tourists, tourist guide can enrich the memory of tourists and their 
general knowledge. Nevertheless, it constitutes a complete picture combines vivid scenes and documented information that help in consolidating the imagination.

\section{Conclusion}

Since the beginning of ancient Egyptian civilization, birds played a fundamental role in daily life activities on one hand and served as a religious symbol on the other. So, thanks to the Old Kingdom artists at Saqqara private tombs, for their precise observation and depiction of one type of bird comfort behaviors like preening with its various movements which was considered one of the bird behaviors that can be easily noticed with its details due to the daily long time that was spent by birds in this activity. 


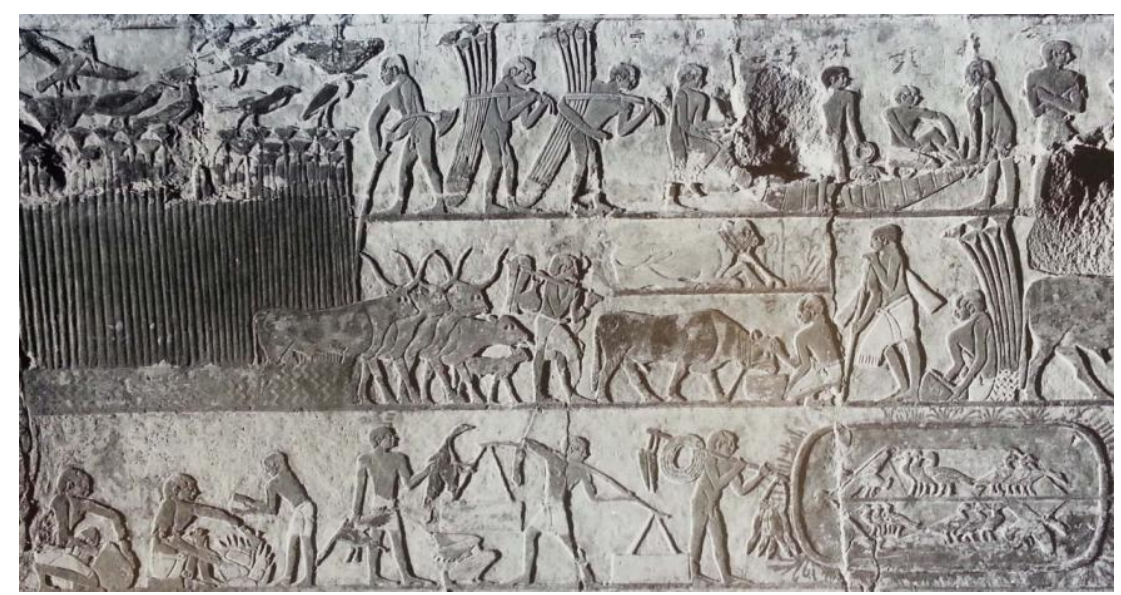

Scene 1-1

After: Moussa and Altenmüller, Tomb of Nefer and Ka-Hay, Pls. 5, 13.

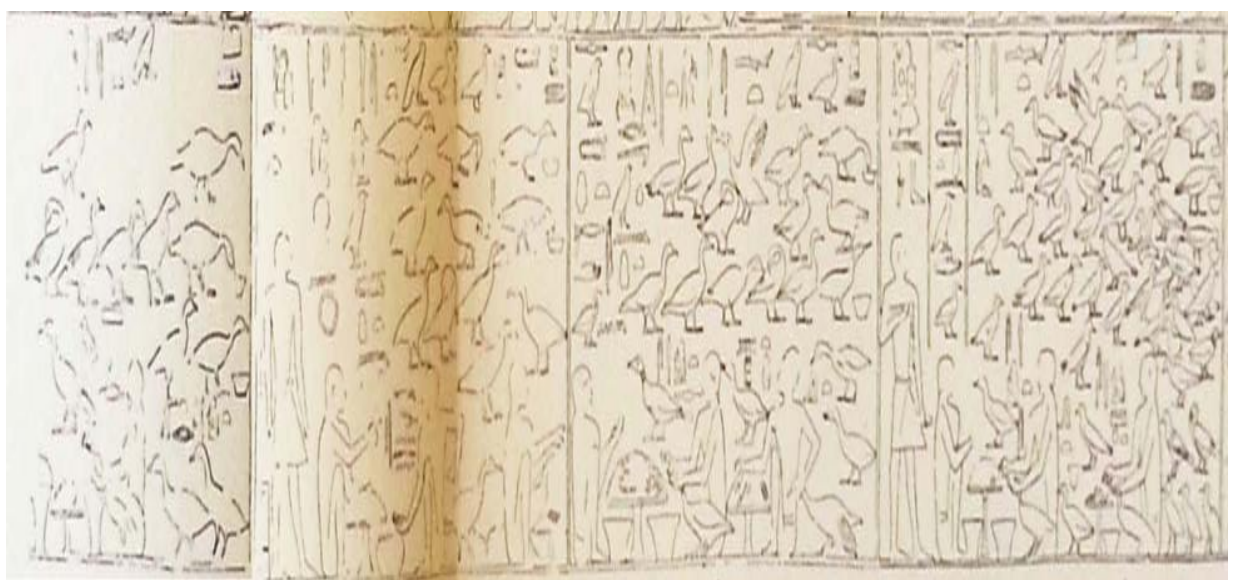

\section{Scene 2-1}

After: Épron and Daumas, "Tombeau de Ti,", Pls. VI, VII, VIII.

Ikram, "Coice Cuts,", 11, fig. 3.

Vandier, Manuel D' Archéologie, fig. 184 a.

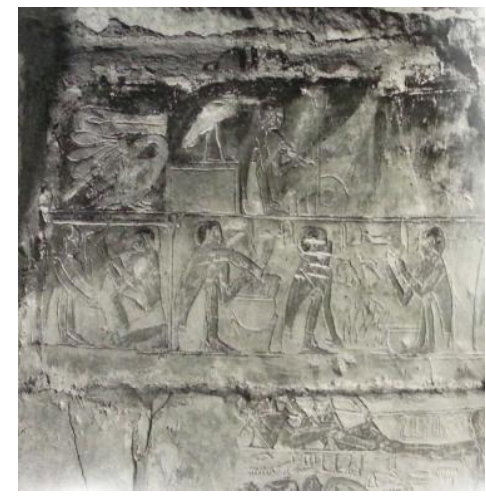

Scene 2-2

After: Altenmüller, Grab des Mehu in Saqqara, Taf. 6.

$$
\text { يحيى، الطبيور المستأنسة في مصر القديمة، شكل .0 }
$$

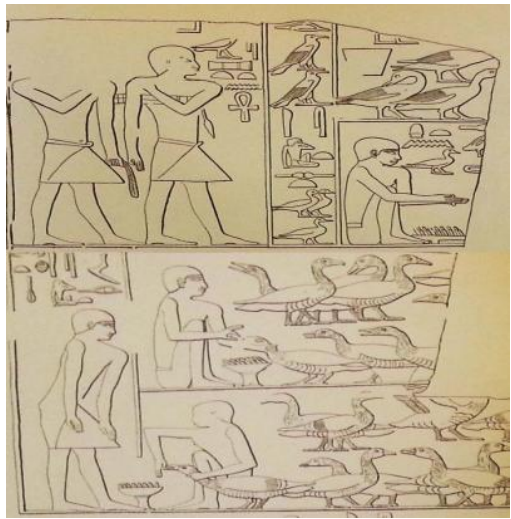

Scene 3-1

After: Épron and Daumas, "Tombeau de Ti," pls. XIX, XXXIII, XXXV.

Walter Wreszinski, Atlas Zur Altägyptischen Kulturgeschishte, Teil III (Leipzig, 1914), Taf. 83. 


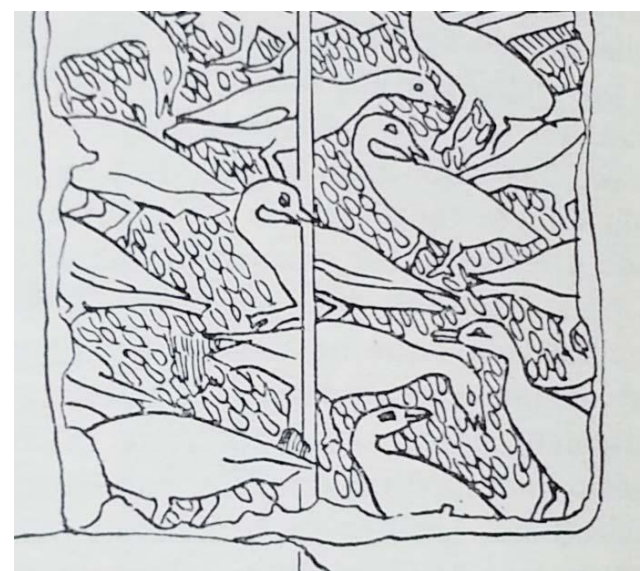

Scene 3-2

After: Vandier, Manuel D'Archéologie, 424, fig. 187.

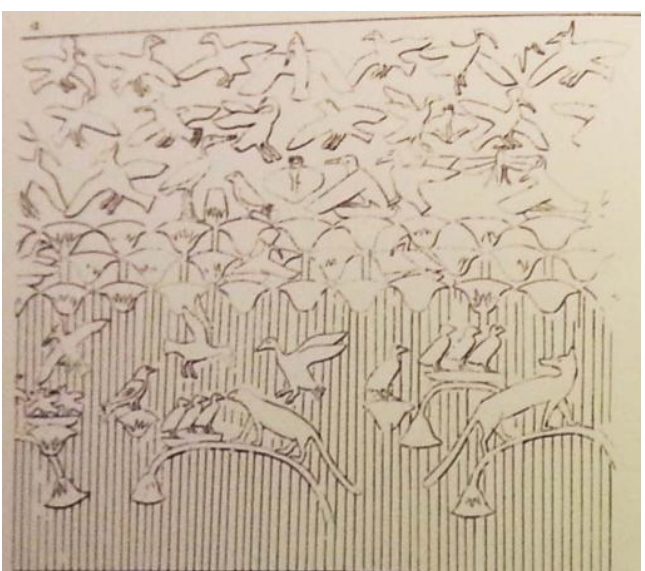

Scene 4-1

After: Davies, The Mastaba of Ptahhetep and Akhethetep, pl. 14.

Vandier, Manuel D' Archéologie, 96, fig. 62.

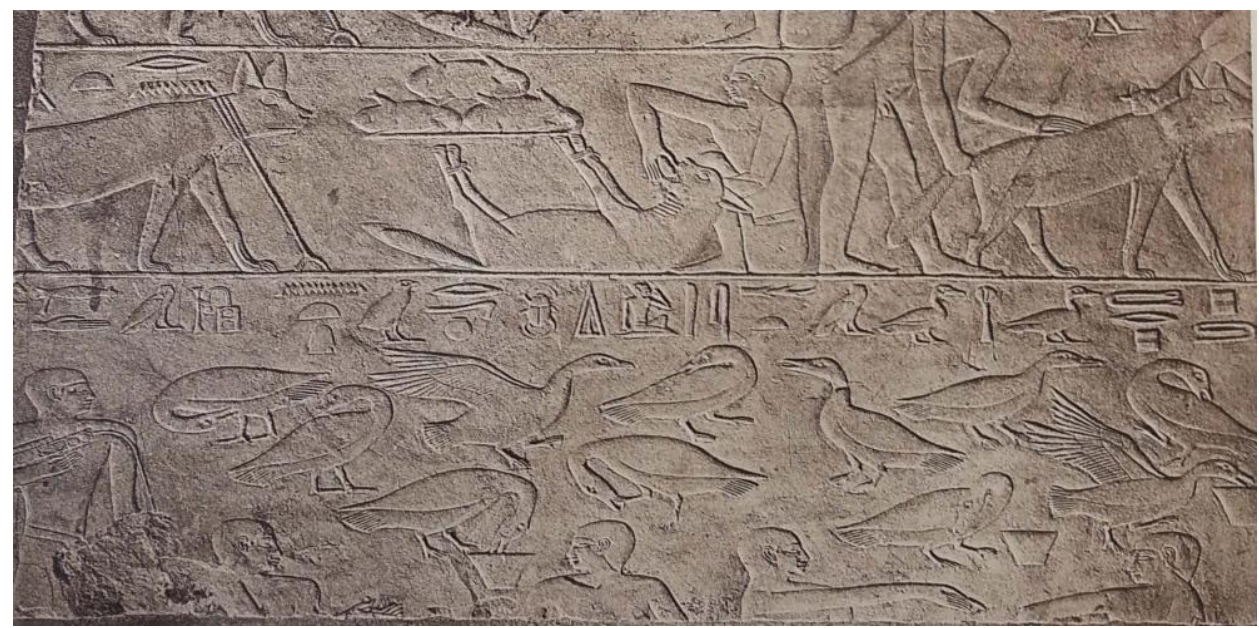

Scene 5-1

After: Harpur and Scremin, Chapel of Kagemni, fig. 13.

Friedrich Wilhelm von Bissing, Mastaba des GEM-NI-KAI, Band I (Berlin, 1905), pls. XI - XII.

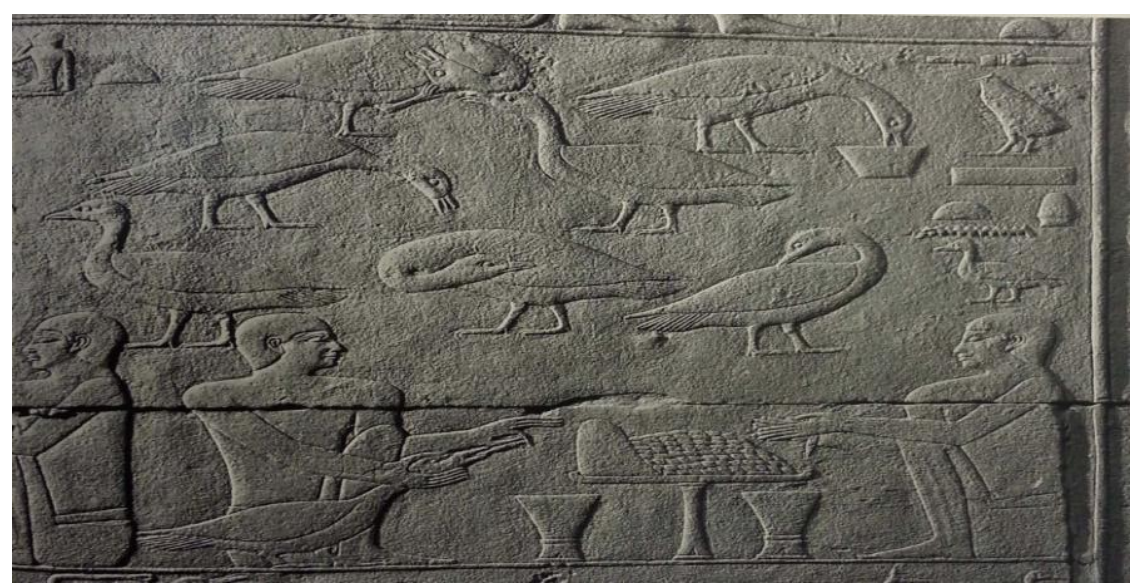

Scene 6-1

After: Harpur and Scremin, Chapel of Kagemni, pls. 195, 202, figs. 13, 14. Bissing, GEM-NI-KAI, pl. XII. 


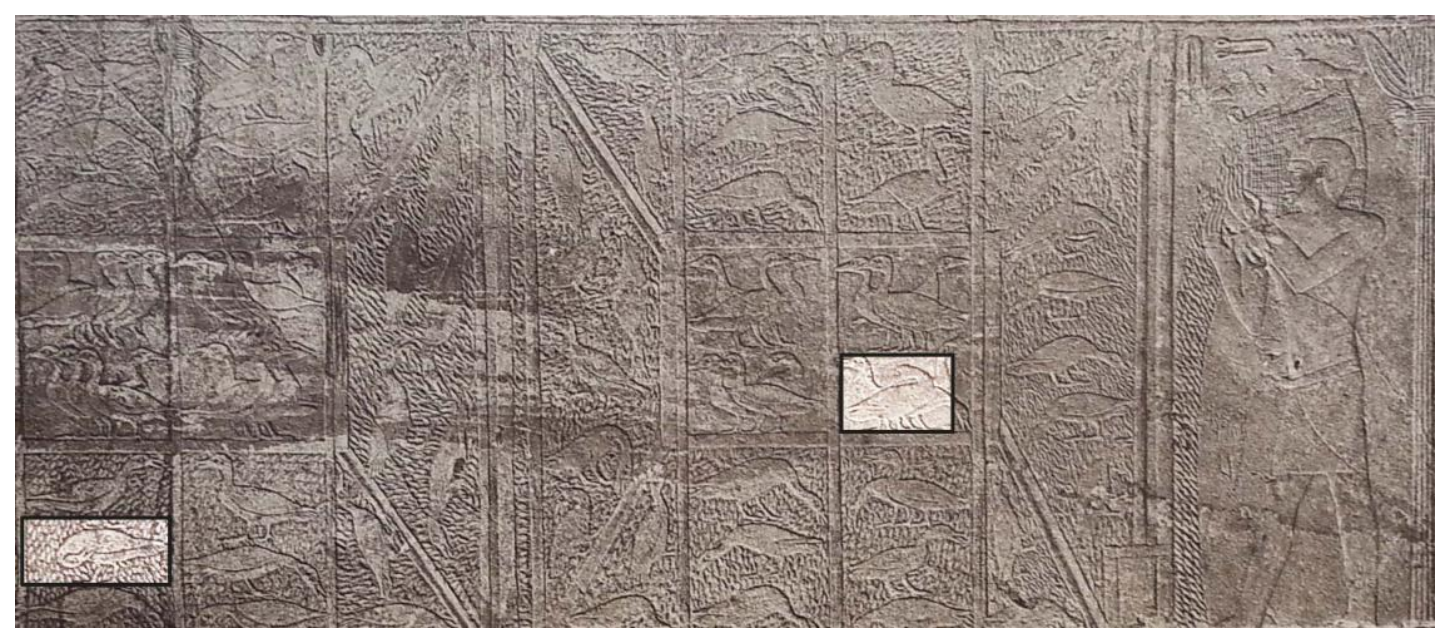

\section{Scene 6 -2}

After: Harpur and Scremin, Chapel of Kagemni, pl. 207, fig. 14.

Bissing, GEM-NI-KAI, Pls. VIII, IX.

Wreszinski, Altägyptischen Kulturgeschishte, Taf. 73.

Luise Klebs, "Die Tiefendinension in der Zeichung des Alten Reiches," ZÄS 52 (1915), 22, Abb. 2. Vandier, Manuel D' Archéologie, fig. 150.

http://archaeologydataservice.ac.uk/archives/view/oee_ahrc_2006/queryThemes.cfm?section=scenes \& theme $=7 \&$ CFID=2642637\&CFTOKEN=70D57FD1-31A8-4023-AAC761C34651F8EC (Last Accessed 21/11/2016).

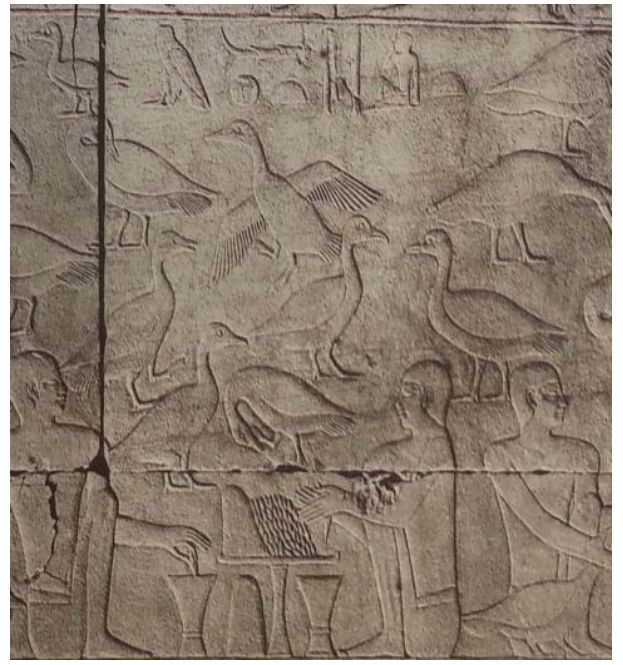

Scene $6-3$

After: Bissing, GEM-NI-KAI, pl. XII. 


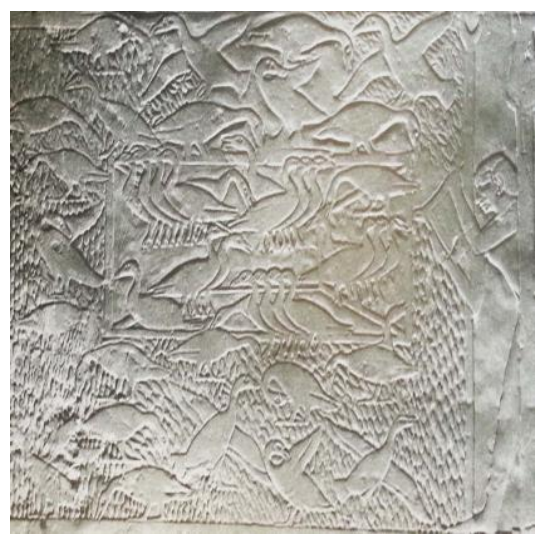

Scene 6 -4

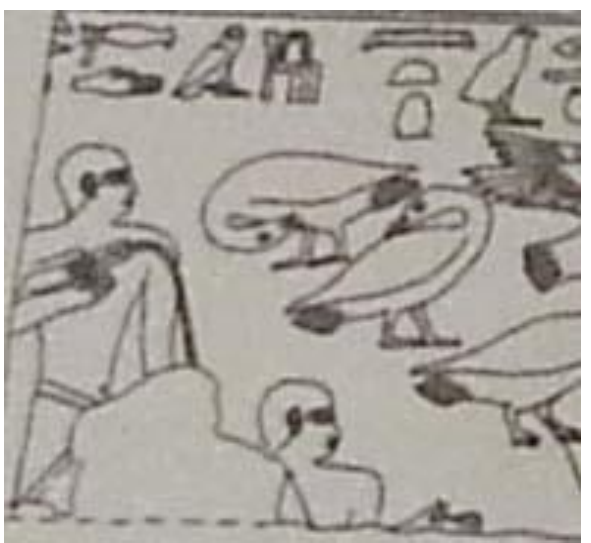

Scene 7- 1

After: Kanawati and Abder-Raziq, Tomb of Hesi, After: Harpur and Scremin, Chapel of Kagemni, pls. 30, 56. fig. 13.

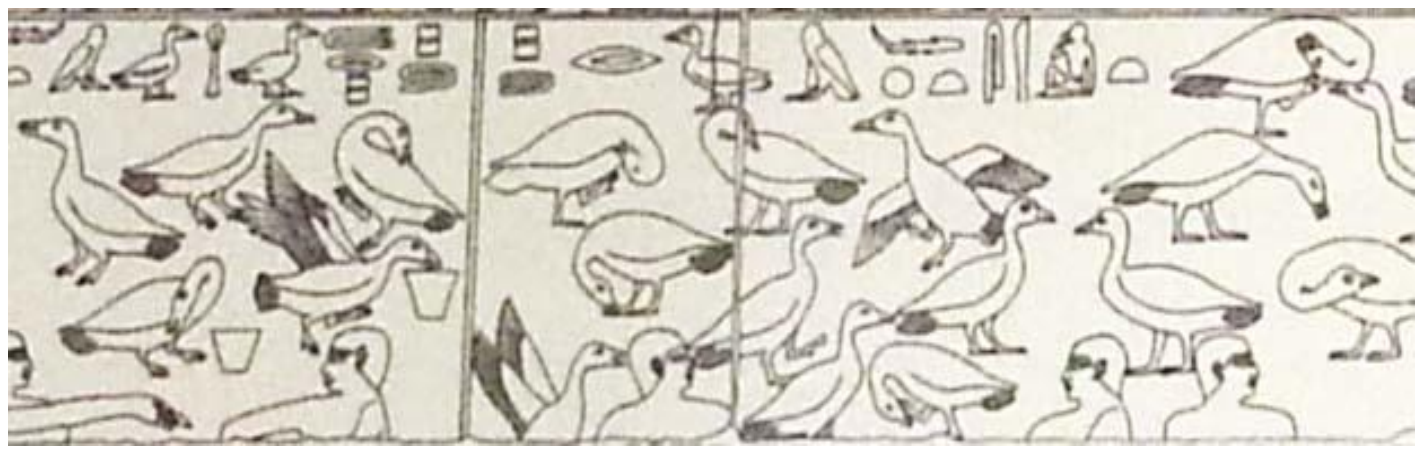

Scene 8-1

After: Harpur and Scremin, Chapel of Kagemni, pl. 201, fig. 13.

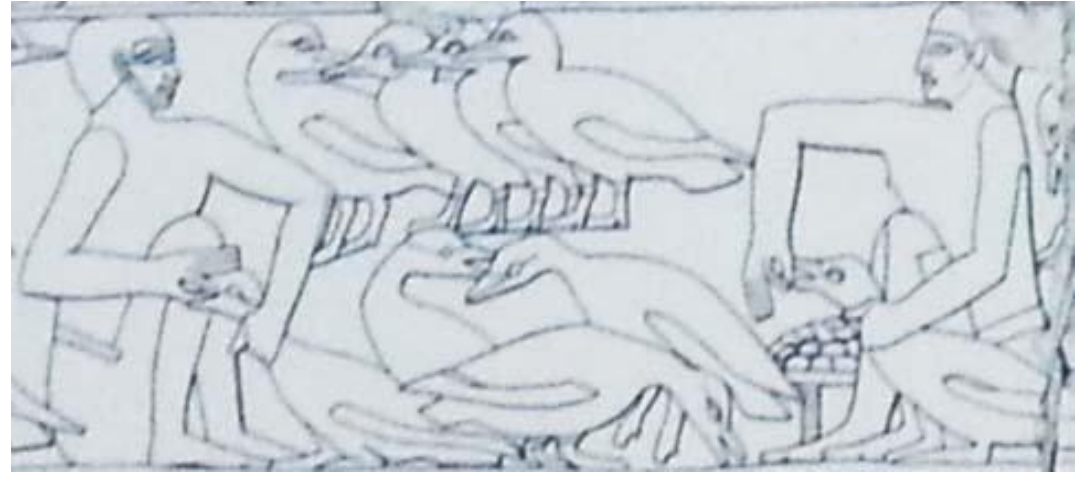

Scene 8-2

After: Duell, "Mastaba of Mereruka," pl. 52.

LeSuer, "Practical Role,", 27, fig. 19. 


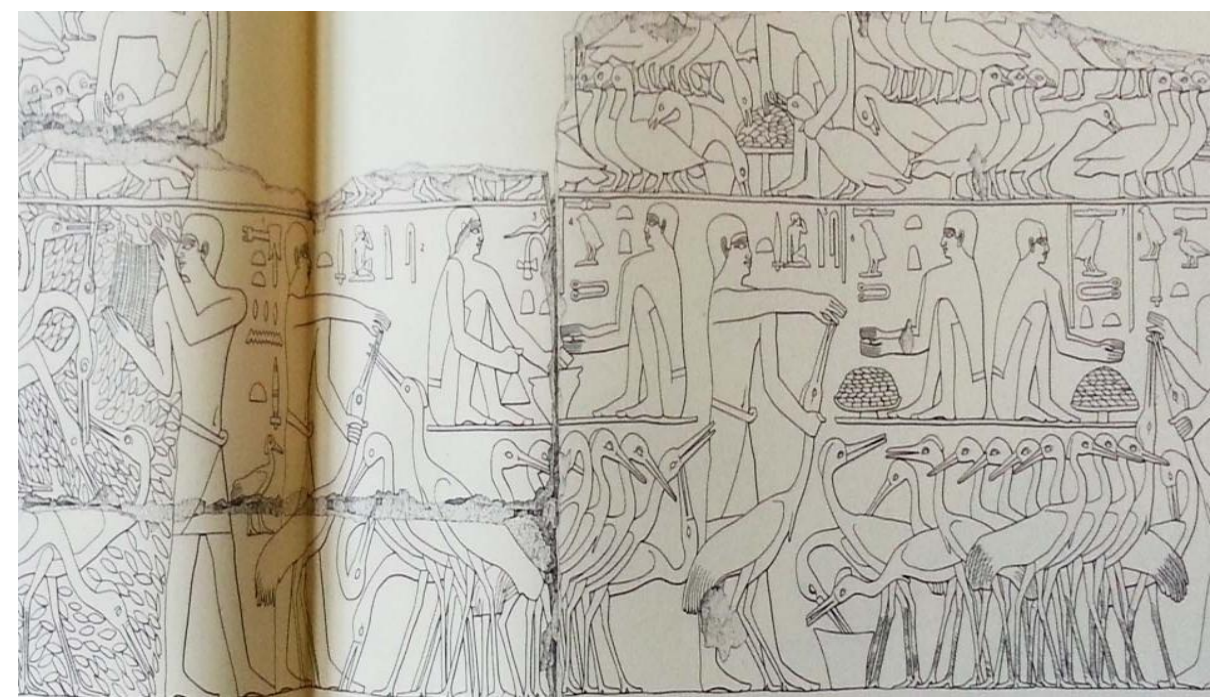

Scene 8-3

After: Duell, "Mastaba of Mereruka," pl. 52.

LeSuer, "Practical Role," 27, fig. 19.

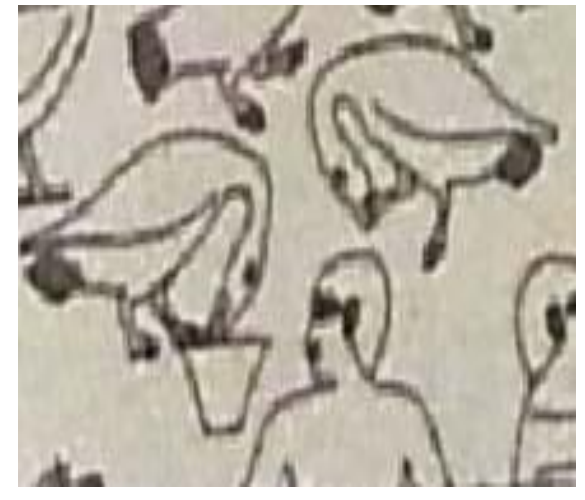

Scene 9-1

After: Harpur and Scremin, Chapel of Kagemni, pl. 200, fig. 13 .

Wreszinski, Altägyptischen Kulturgeschishte, Taf. 79.

Joachim Boessneck, Die Tierwelt die Alten Ägypten (München, 1988), fig. 168.

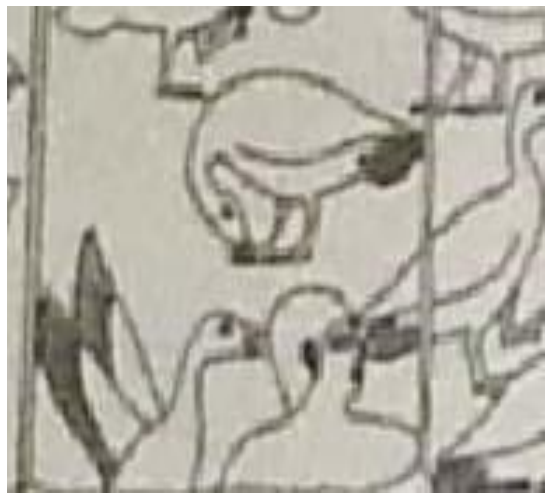

\section{Scene 9- 2}

After: Harpur and Scremin, Chapel of Kagemni, fig. 13.

Wreszinski, Altägyptischen Kulturgeschishte, Taf. 79.

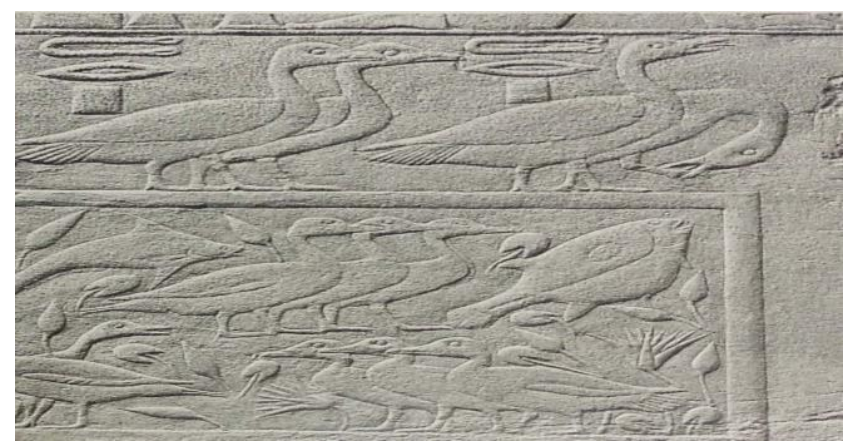

\section{Scene 9- 3}

After: Harpur and Scremin, Chapel of Kagemni, pl. 209, fig. 13.

Bissing, GEM-NI-KAI, pl. X.

Wreszinski, Altägyptischen Kulturgeschishte, Taf. 79.

Vandier, Manuel D'Archéologie, fig. 182. 


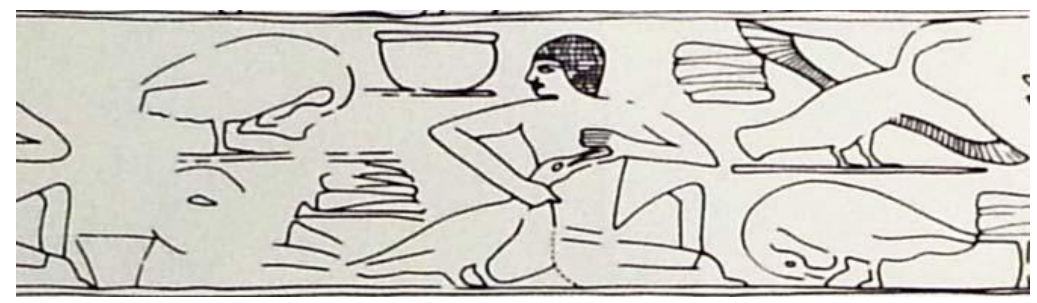

Scene 9-4

After: Davis, El-Khouli, Lloyd and Spencer, Mastabas of Mereri and Wernu, pl. 6A.

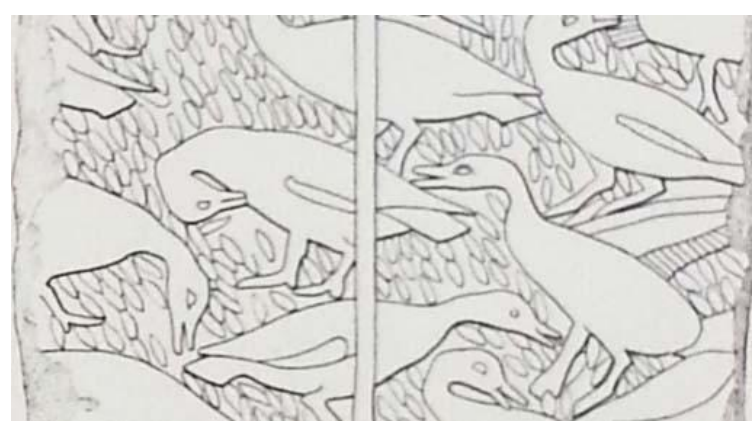

Scene 10-1

After: Duell, "Mastaba of Mereruka," pl. 53 B.

Harrison, "Allopreening as Agonistic," 176, fig. 5.

Vandier, Manuel D' Archéologie, 424, fig. 187.

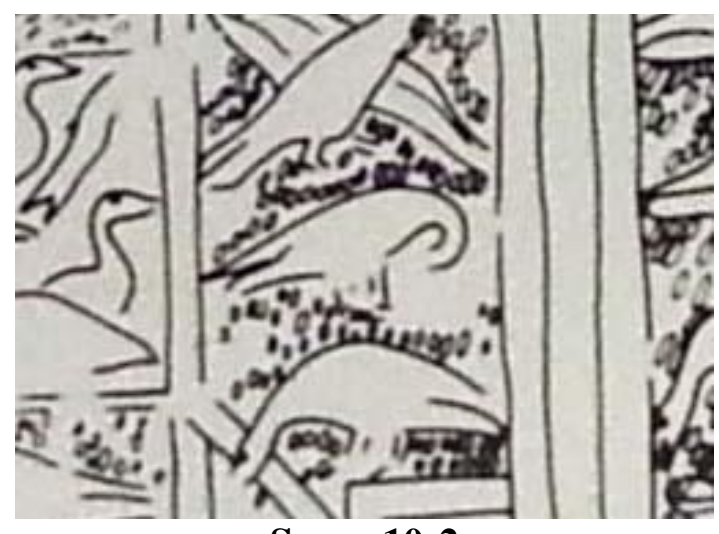

Scene 10-2

After: Davis, El-Khouli, Lloyd and Spencer, Mereri and Wernu, pl. 6A.

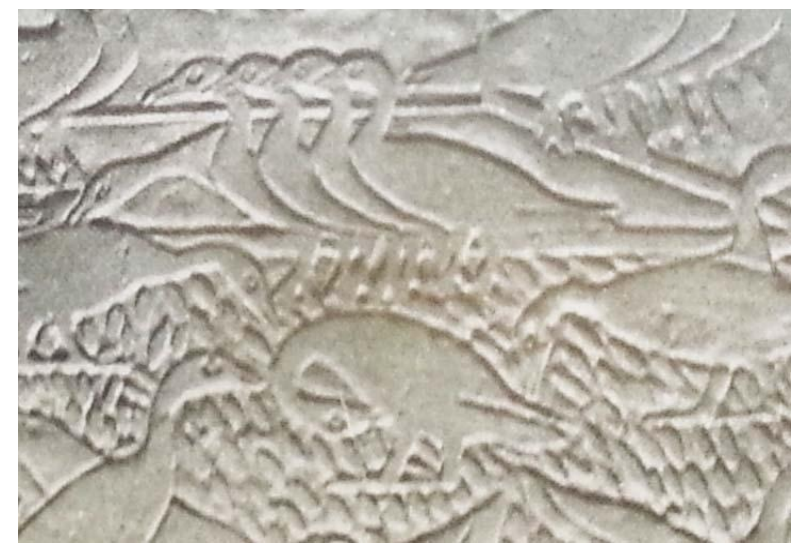

Scene 10-3

After: Kanawati and Abder-Raziq, Tomb of Hesi, 34, pls. 30, 56. 


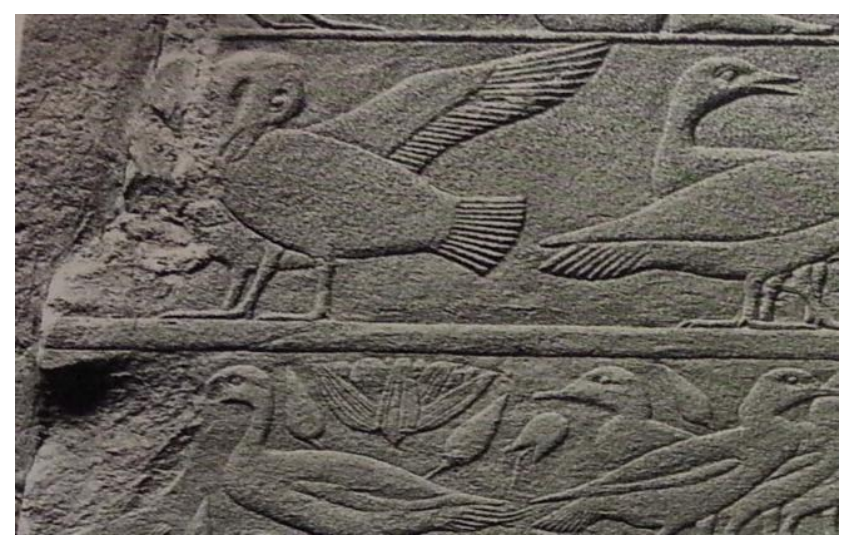

Scene 10-4

Harpur and Scremin, Chapel of Kagemni, 134, pl. 209.

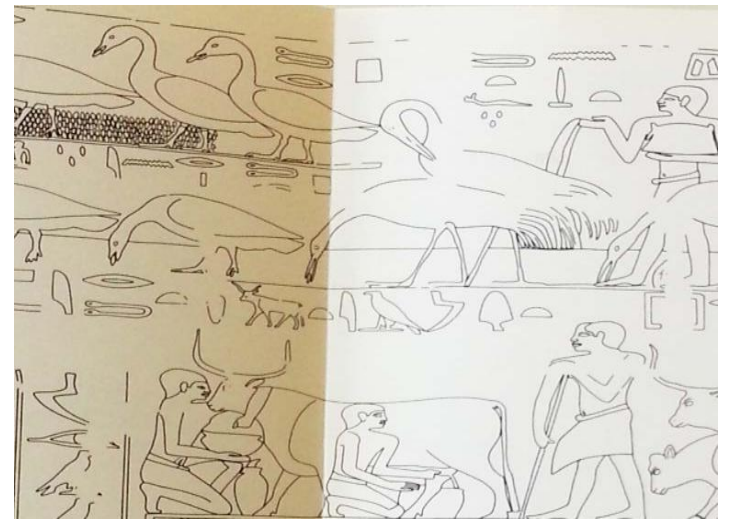

Scene 10-5

After: Kanawati and Abder-Raziq, Tomb of Nikauisesi, pl. 49.

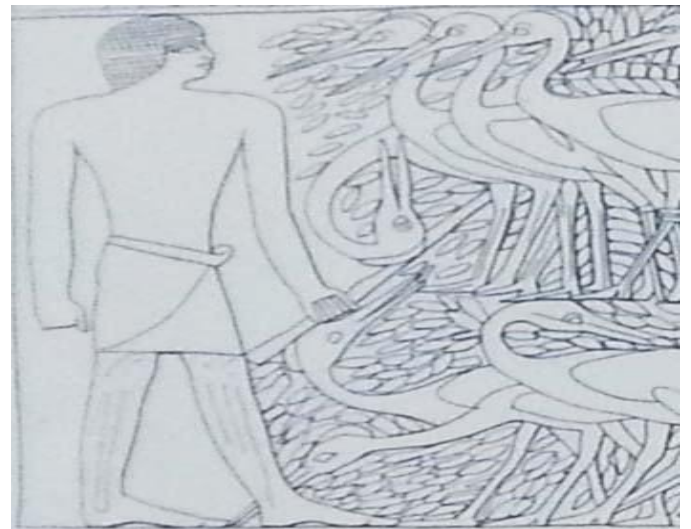

Scene 10-6

After ; Duell, "Mastaba of Mereruka," pl. 52. LeSuer, "Practical Role," 27, fig. 19. 
${ }^{1}$ H. Te Velde, "A Few Remarks upon the Religious Significance of Animals in Ancient Egypt," Numen XXVII, Fasc.1 (1980), 76.

Linda Evans, Animal Behavior in Egyptian Art (Oxford, 2010), 1.

${ }^{2}$ Patrick F. Houlihan, "Animals in Egyptian Art and Hieroglyphs," in Billie Jean Collins, ed., A History of the Animal World in the Ancient Near East (Brill, 2002), 97.

${ }^{3}$ Evans, Animal Behavior, 1.

${ }^{4}$ Evans, Animal Behavior, 1.

${ }^{5}$ Houlihan, "Animals in Egyptian Art and Hieroglyphs," 98.

${ }^{6}$ Evans, Animal Behavior, 1.

${ }^{7}$ Yvonne Harpur, Decorations in Egyptian Tombs of the Old Kingdom (London, 1987), 175.

${ }^{8}$ Evans, Animal Behavior, 5.

${ }^{9}$ Gay Robins, "Problems in Interpreting Egyptian Art," DE 17 (1990), 45- 58.

${ }^{10}$ Micheal D. Bread with Janice Moore, Animal Behavior (USA, 2016), 4.

Aubrey Manning with Marian Stamp Dawkins, Animal Behaviour (Cambridge, 1998), 1.

${ }^{11}$ Joel Carl Welty, The Life of Birds (USA, 1982), 191,192.

Bread and Moore, Behavior, 4.

${ }^{12}$ Evans, Animal Behavior, 13.

${ }^{13}$ Evans, Animal Behavior, 14.

${ }^{14}$ Evans, Animal Behavior, 15.

${ }^{15}$ Evans, Animal Behavior, 15, 16, 24.

${ }^{16}$ Evans, Animal Behavior, 27.

${ }^{17}$ Patrick F. Houlihan, "Birds," in D. Redford, ed., The Oxford Encyclopedia of Ancient Egypt, vol. 1 (Oxford, 2001), 189-191.

Patrick F. Houlihan, "Poultry," in D. Redford, ed., The Oxford Encyclopedia of Ancient Egypt, vol. 1 (Oxford, 2001), 59 - 61.

Patrick F. Houlihan, The Animal World of the Pharaohs (Cairo, 1996), 134.

Steven M. Goodman with Peter L. Meininger, The Birds of Egypt (Oxford, 1989), 5.

* Ogden Goelet, "The Migratory Geese of Meidum and Some Egyptian Words for (Migratory Bird)," BES 5 (1983), 41- 60.

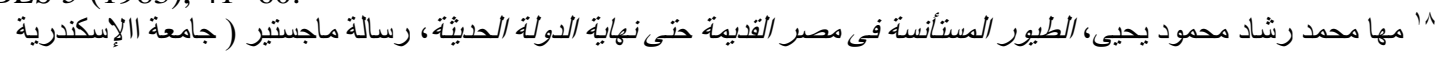

${ }^{19}$ Frederick E. Zeuner, A History of Domesticated Animals (London, 1963), 468, 474.

Houlihan, "Birds," 189 - 191.

Houlihan, "Poultry," 59 - 61.

I. G. Walleret, "Ente," in W. Helck and E. Otto, eds., Lexikon der Ägyptologie, Band I (Wiesbaden, 1975), 1228, 1229.

${ }^{20}$ Salima Ikram, "Coice Cuts: Meat Production in Ancient Egypt," OLA 69 (1995), 7.

${ }^{21}$ Ikram, "Coice Cuts," 24.

${ }^{22}$ Salima Ikram, "Diet," in D. Redford, ed., The Oxford Encyclopedia of Ancient Egypt, vol. 1 (Oxford, 2001), 391.

${ }^{23}$ Ikram, "Coice Cuts," 27.

${ }^{24}$ Ikram, "Coice Cuts," 25.

${ }^{25}$ Patrick F. Houlihan with Steven M. Goodman, The Birds of Ancient Egypt (England, 1986), 21. Sylvie Cauville, Offerings to the Gods in Egyptian Temples (Leuven, 2012), 83.

${ }^{26}$ Houlihan, "Birds," 189 - 191.

Houlihan, "Poultry," 59 - 61.

${ }^{27}$ Houlihan, "Birds," 189 - 191.

Houlihan, "Poultry," 59 - 61.

Rozenn Bailleul-LeSuer, "The Practical Role of Birds in Ancient Egypt," OIMP 35 (2012), 27 -30.

${ }^{28}$ Robert K. Ritner, "Magic in the Afterlife," in D. Redford, ed., The Oxford Encyclopedia of Ancient Egypt, vol. 2 (Oxford, 2001), 333.

LeSuer, "Practical Role," 30.

Hannes Buchberger, "Vogel," in W. Helck and E. Otto, eds., Lexikon der Ägyptologie, Band VI (Wiesbaden, 1986), $1046-1051$.

Ikram, "Coice Cuts," 24.

${ }^{29}$ Peter Behrens, "Geflügel," in W. Helck and E. Otto, eds., Lexikon der Ägyptologie, Band II (Wiesbaden, 1977), 503. 
Alan Gardiner, Egyptian Grammar (Oxford, 1976), 473.

${ }^{30}$ Emily Teeter, "Animals in Egyptian Religion," A History of the Animal World, Part IV (Brill, 2002), 346, fig. 12.3 .

Ikram, "Coice Cuts," 24.

LeSuer, "Practical Role," 35.

Naguib Kanawati, The Tomb and Beyond (England, 2001), 24, figs. 11, 12.

${ }^{31}$ LeSuer, "Practical Role," 35.

${ }^{32}$ J. Vandier, "Les Singes Familiers Dans L'Ancienne Égypte,"RdE 16 (1964), 147.

Houlihan, "Animals in Egyptian Art and Hieroglyphs," 102.

Te Velde, "Few Remarks," 79.

Henri Frankfort, Ancient Egyptian Religion (New York, 1961), 8 -14.

Erik Hornung, Conceptions of God in Ancient Egypt (London, 1982), 123.

${ }^{33}$ Ikram, "Coice Cuts," 24.

${ }^{34}$ Rosalind with Jack Janssen, Egyptian Household Animals (UK, 1989), 46.

Cauville, Offerings to the Gods, 83.

${ }^{35}$ Harpur, Decorations in Egyptian Tombs, 8.

${ }^{36}$ William Stevenson Smith, Interconnections in the Ancient Near East (New York, 1965), 139.

William Stevenson Smith, A History of Egyptian Sculpture and Painting in the Old Kingdom (Oxford, 1949), 155.

Houlihan, "Poultry," 59-61.

${ }^{37}$ Kamil O. Kurasziewicz, "Orientation of the Old Kingdom Tombs in Saqqara," ÉtTrav XXVI (2013), 396.

${ }^{38}$ H. A. Groenewegen-Frankfort, Arrest and Movement (London, 1951), 31.

${ }^{39}$ Naguib Kanawati with Alexandra Woods, Artists of the Old Kingdom (Cairo, 2009), 2.

Houlihan, "Poultry," 59-61.

${ }^{41}$ Juliet Clutton-Brock, Domesticated Animals (London, 1981), 21.

Douglas J. Brewer, Donald B. Redford and Susan Redford, Domestic Plants and Animals (England, 1994), 1.

${ }^{42}$ Houlihan, "Poultry," $59-61$.

${ }^{43}$ A. F. Fraser with D. M. Broom, Farm Animal Behaviour and Welfare (England, 1990), 99.

${ }^{44}$ Michael Allaby, Oxford Dictionary of Zoology (Oxford, 2009), 277.

${ }^{45}$ Evans, Animal Behavior, 75- 83.

${ }^{46}$ Evans, Animal Behavior, 75- 83.

${ }^{47}$ Allaby, Zoology, 506.

Frank B. Gill, Ornithology (New York, 2007), 102, 103, fig. 4-13.

Robert Burton, Bird Behaviour (London, 1985), 30.

Robert Burton, Das Leben der Vögel (London, 1985), 30.

A. Landsborough Thomson, A New Dictionary of Birds (London, 1964), 278.

${ }^{48}$ Allaby, Zoology, 506.

Gill, Ornithology, 102, 103, fig. 4-13.

Burton, Bird Behaviour, 30.

Burton, Das Leben, 30.

Thomson, Dictionary of Birds, 280.

${ }^{49}$ Bread and Moore, Behavior, 141.

${ }^{50}$ Norman Elkins, Weather and Bird Behaviour (Calton, 1983), 99.

Thomson, Dictionary of Birds, 280.

${ }^{51}$ Evans, Animal Behavior, 77, 78, pls. 6E, 6F, 6G.

${ }^{52}$ K. E. L. Simmons, "The Taxonomic Significance of Head Scratching Methods of Birds," Ibis 99 (1957), 178.

Thomson, Dictionary of Birds, 281, 282.

${ }^{53}$ F. Mckinney, "The Comfort Movements of Anatidae," Behaviour 25 No. 1/2 (1965), 154, fig. 13. Linda Evans, "Bird Behavior in Ancient Egyptian Art," OIMP 35 (2012), 93.

${ }^{54}$ Evans, Animal Behavior, 77, 78, pls. 6E, 6F, 6G.

${ }^{55}$ Burton, Bird Behaviour, 30 -33.

${ }^{56}$ Burton, Bird Behaviour, 33.

Evans, Animal Behavior, 78.

${ }^{57}$ C. J. O. Harrison, "Allopreening as Agonistic Behaviour," Behaviour 24 No. 3/4 (1964), 161-209. 
${ }^{58}$ Burton, Bird Behaviour, 33.

Evans, Animal Behavior, 80.

${ }^{59}$ Evans, Animal Behavior, 80, pl. $6 \mathrm{H}$.

${ }^{60}$ Evans, Animal Behavior,78.

${ }^{61}$ Harpur, Decorations in Egyptian Tombs, 9, 274.

Evans, Animal Behavior, 78, 244, 245, 333.

${ }^{62}$ Evans, Animal Behavior, 244, 333.

${ }^{63}$ Bertha Porter with Rosalind L. B. Moss, Topographical Bibliography of Ancient Egyptian

Hieroglyphic Texts, Reliefs, and Paintings, III ${ }^{2}$. Memphis (Oxford, 1979), 639, Map. LXII.

${ }^{64}$ Evans, Animal Behavior, 78, fig.6 -9, pl. 6E.

Porter and Moss, Topographical Bibliography, 640, Plan. LXV.

Ahmed M. Moussa with Hartwig Altenmüller, The Tomb of Nefer and Ka-Hay (Mainz, 1971), $22,23$. pl. 5,13 .

${ }^{65}$ Alessandra Nibbi, Lapwings and Libyans in Ancient Egypt (Oxford, 1986), 11-19.

Philippe Germond, Bestiaire Égyptien (Paris, 2001), 37 - 39.

${ }^{66}$ Porter and Moss, Topographical Bibliography, 468, Plan. XLVIII.

${ }^{67}$ Kanawati and Woods, Artists, 48.

Patrick F. Houlihan, "A Guide to the Wildlife Represented in the Great Swampland Scene in the

Offering-chapel of Ti (No. 60) at Saqqara," GM 155 (1996), 19.

${ }^{68}$ Porter and Moss, Topographical Bibliography, 468, Plan. XLVIII.

${ }^{69}$ Evans, Animal Behavior, 245, 333.

Kanawati and Woods, Artists, 48.

${ }^{70}$ Harpur, Decorations in Egyptian Tombs, 277.

Evans, Animal Behavior, 245, 333.

${ }^{71}$ Lucienne Épron with François Daumas, Le Tombeau de Ti, MIFAO LXV (1939), pls. I, VI.

Evans, Animal Behavior, 78, 245.

${ }^{72}$ Porter and Moss, Topographical Bibliography, 469.

${ }^{73}$ Evans, Animal Behavior, 78, fig. 6-10, pl. 6F.

74 Alfred Hermann, "Das Motiv der Ente mit Zurückgewendetem Kopfe im ägyptischen Kunstgewerbe," Z̈̈S 68 (1932), Taf. VII, VIII.

Walleret, "Ente," 1228, 1229.

${ }^{75}$ Evans, Animal Behavior, 80, fig. 6-28.

${ }^{76}$ Hartwig Altenmüller, Die Wanddarstellungen im Grab des Mehu in Saqqara (Mainz, 1998), 91.

Porter and Moss, Topographical Bibliography, 619. Plan. LXIII.

${ }^{77}$ Porter and Moss, Topographical Bibliography, 619. Plan. LXIII.

Kanawati and Woods, Artists, 50.

${ }^{78}$ Porter and Moss, Topographical Bibliography, 619. Plan. LXIII.

Kanawati and Woods, Artists, 50.

${ }^{79}$ Prentice Duell, "The Mastaba of Mereruka," OIP XXXI (1938), pl. 53.

J. Vandier, Manuel D' Archéologie Égyptienne, vol. V (Paris, 1969), 424, fig. 187.

${ }^{80}$ Porter and Moss, Topographical Bibliography, 525.

${ }^{81}$ Porter and Moss, Topographical Bibliography, 525, pl. LVI, Map. LII.

${ }^{82}$ Evans, Animal Behavior, 78, fig. 6 - 12.

${ }^{83}$ Porter and Moss, Topographical Bibliography, 599, Plan. LX.

Harpur, Decorations in Egyptian Tombs, 272.

Evans, Animal Behavior, 245.

${ }^{84}$ Porter and Moss, Topographical Bibliography, 599.

N. De G. Davies, The Mastaba of Ptahhetep and Akhethetep at Saqqara, Part II (London, 1901), 14, pl. $1,14$.

${ }^{85}$ Porter and Moss, Topographical Bibliography, 599.

${ }^{86}$ Robert E. Goodwin, "Records of Flight Preening and Related Aerial Activities in Birds, Particularly the Black Tern," The Auk 76, No. 4 (1959), 521.

${ }^{87}$ Porter and Moss, Topographical Bibliography, 521- 525, pl. LV.

${ }^{88}$ Porter and Moss, Topographical Bibliography, 523.

${ }^{89}$ Evans, Animal Behavior, 79, fig. $6-20$.

${ }^{90}$ Evans, Animal Behavior, 79, fig. 6-19.

${ }^{91}$ Yvonne Harpur with Paolo Scremin, The Chapel of Kagemni (Oxford, 2006), 408. 
${ }^{92}$ Harpur and Scremin, Chapel of Kagemni, 132, 410.

${ }^{93}$ Harpur and Scremin, Chapel of Kagemni, 407, 408.

Porter and Moss, Topographical Bibliography, 523.

${ }^{94}$ Naguib Kanawati with M. Abder-Raziq, The Teti Cemetery at Saqqara, vol. V, The Tomb of Hesi (England, 1999), 34.

${ }^{95}$ Evans, Animal Behavior, 79, fig. 6 - 13.

${ }^{96}$ Porter and Moss, Topographical Bibliography, 523.

${ }^{97}$ Evans, Animal Behavior, 79.

Harpur and Scremin, Chapel of Kagemni, 407, 408.

${ }^{98}$ Evans, Animal Behavior, 79.

${ }^{99}$ Duell, "Mastaba of Mereruka," pl. 152.

${ }^{100}$ Evans, Animal Behavior, 79.

${ }^{101}$ Evans, Animal Behavior, 79.

102 Porter and Moss, Topographical Bibliography, 523.

${ }^{103}$ Harpur and Scremin, Chapel of Kagemni, 209.

${ }^{104}$ W. V. Davis, A. El-Khouli, A. B. Lloyd with A. J. Spencer, Saqqara Tombs I, The Mastabas of Mereri and Wernu (London, 1984), 11, 12.

${ }^{105}$ Porter and Moss, Topographical Bibliography, 518, pl. LV, Map. LII.

${ }^{106}$ Mckinney, "Movements of Anatidae," 154, fig. 13.

${ }^{107}$ Evans, Animal Behavior, 79.

${ }^{108}$ Porter and Moss, Topographical Bibliography, 525.

${ }^{109}$ Davis, El-Khouli, Lloyd and Spencer, Mastabas of Mereri and Wernu, 12.

${ }^{110}$ Kanawati and Abder-Raziq, Tomb of Hesi, 34.

${ }^{111}$ Harpur and Scremin, Chapel of Kagemni, 411.

112 Naguib Kanawati with M. Abder-Raziq, The Teti Cemetery at Saqqara, vol. VI, The Tomb of Nikauisesi (England, 1999), 38.

${ }^{113}$ Duell, "Mastaba of Mereruka," pl. 52.

Porter and Moss, Topographical Bibliography, 525.

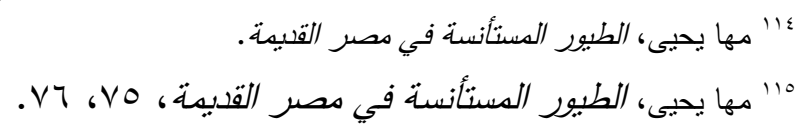

